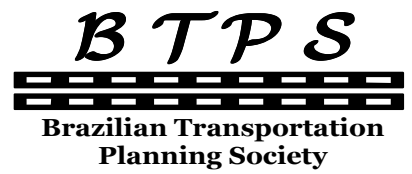

Journal of Transport Literature

Vol. 7, n. 2, pp. 297-318, Apr. 2013

Research Directory

JTLIRELIT

www.transport-literature.org

Planning Society

\title{
Intelligent transport systems and regional digital convergence in Greece
}

[Sistemas de transporte inteligentes e convergência digital regional na Grécia]

\author{
Theodore Tsekeris*, Charalambos Tsekeris, Konstantinos Koskinas, Michael Lavdas \\ Centre of Planning and Economic Research (KEPE), Greece, Panteion University of Social and Political Sciences, Greece, \\ Panteion University of Social and Political Sciences, Greece, Panteion University of Social and Political Sciences, Greece
}

Submitted 24 Jun 2012; received in revised form 6 Aug 2012; accepted 9 Sep 2012

\begin{abstract}
This paper investigates the aspects of regional digital convergence, i.e. the capability of the use of Information and Communication Technologies (ICTs) among all people living in the peripheral areas of a country, in relation to the ICT applications into the transport sector, known as Intelligent Transport Systems (ITS). It also examines the interdependent relationships between the digital and physical accessibility. Firstly, the ICT infrastructures and their access via the households and enterprises set the conditions for the use of ITS. On the other hand, the expansion of transport networks and decentralization of transport flows can contribute to the widespread adoption of ITS and ICTs in general, and the higher specialization and diversification of digital services. These interactions are analyzed in Greece, through investigating the spatial allocation of public expenditure, at a regional level, for the Information Society and the transport sector, during 2000-2009. The findings indicate that the increased concentration of public investments in road projects in peripheral areas does not imply the bridging of the digital gap between the metropolitan areas (Athens and Thessaloniki) and the rest of Greece. The need for designing a comprehensive regional investment policy is suggested to jointly reinforce the digital convergence and physical accessibility.
\end{abstract}

Key words: intelligent transport systems, digital convergence, public investment, regional development, Greece.

\section{Resumo}

Este trabalho investiga os aspectos da convergência digital regional, ou seja, a capacidade de uso das Tecnologias de Comunicação e Informação (Information and Communication Technologies, ICTs) entre a população que habita as áreas periféricas de um país, em relação às aplicações destas tecnologias no setor de transporte, mais conhecido como Sistemas de Transporte Inteligentes (ITS). Também são examinadas as relações entre a acessibilidade física e digital. 0 acesso à infraestrutura de ICT nas residências e nas empresas é a condição primária para o uso do ITS. Por outro lado, a expansão da rede de transporte e a descentralização dos seus fluxos contribuem com a adoção difundida do ITS e ICTs, além de promover uma maior especialização e diversificação dos serviços digitais. Estas interações são analisadas na Grécia através da investigação da alocação espacial dos gastos públicos em nível regional pela Sociedade de Informações e pelo setor de transporte, durante os anos de 2000-2009. Os resultados indicam que o aumento da concentração dos investimentos públicos em projetos de vias nas áreas periféricas não implica na superação das diferenças de acesso digital entre as áreas metropolitanas (Atenas e Thessalonica) e o restante da Grécia. A necessidade de projetar políticas de investimentos regionais sugere um esforço conjunto entre a convergência digital e a acessibilidade física.

Palavras-Chave: sistemas de transporte inteligentes, convergência digital, investimento público, desenvolvimento regional, Grécia.

*Email: tsek@kepe.gr.

\section{Recommended Citation}

Tsekeris, T., Tsekeris, C., Koskinas, K. and Lavdas, M. (2013) Intelligent transport systems and regional digital convergence in Greece. Journal of Transport Literature, vol. 7, n. 2, pp. 297-318.

- JTL/RELIT is a fully electronic, peer-reviewed, open access, international journal focused on emerging transport markets and published by BPTS - Brazilian Transport Planning Society. Website www.transport-literature.org. ISSN 2238-1031. 


\section{Introduction}

The main object of this paper is the joint investigation of the spatial investment patterns and activities in the sectors of transport and Information and Communication Technologies (ICTs) in Greece. This investigation aims at supporting a more equitable and consistent strategic decision-making framework for the regional allocation of resources among these sectors. Regarding the spatial and social dimensions of equity, digital convergence refers to the process of electronically interconnecting all the areas of a country and especially the remote peripheral areas, while offering to every single group of the population the ability to use ICTs. Greece ranks among the stragglers in the European Union (EU) concerning the infrastructure of broadband digital networks, while significant deviation is noticed among urban, rural, island and mountain areas, as well as the whole country concerning the access to broadband networks (IPOIO, 2007; OIS, 2009a). Interconnectivity and use of ICTs focus on prosperous and dynamic urban centres-poles, principally located across the development axis between Patra, Athens and Thessaloniki. This pattern of geography confirms the bond that exists between the development of physical accessibility and connectivity to the internet and other digital applications.

This bond has been widely observed across Europe, where the backbones of information (internet) and (tele)communication networks largely follow existing patterns of high (road, rail, air) accessibility, nodes of transport provision and urban concentrations of knowledge (Billón et al., 2008; Tranos and Gillespie, 2009). Such interrelationships can be attributed to the common natures of ICT and transport infrastructures, which are characterized by economies of scale and scope. The economies of scale can be ascribed to the technical and systemic characteristics (including indivisibilities) of these infrastructures, which usually imply increasing returns to scale and the continuation of relevant projects over a period that exceeds the calendar year. Specifically, ICT networks typically follow previous layers of network infrastructure, since this facilitates their installation; for instance, the development of fibre cable networks next to or underneath existing road or rail networks, compared to building a new network from scratch (Rutherford, 2005). In addition, ICTs are generalpurpose technologies that are essential for the maintenance and growth of production, and the distribution and exchange of goods and services (Batty, 1997). The economies of scope imply 
the per-unit cost reductions associated with increasing the scale of production of more than one type of (indivisible physical) infrastructure or service. An efficient product differentiation can be obtained from synergies between the infrastructure of transport systems and their information management through ICTs, which can enhance physical accessibility. It has been found that, in certain small or medium sized urban centres in peripheral areas of Greece, the local enterprises tend to overcome the shortage and hurdles in physical accessibility through the increased use of internet (Asprogerakas and Ioannou, 2007).

Regional and sectoral policies for the treatment of the digital isolation of remote areas of the country as well as of the inequalities in the access and use of ICTs are anticipated to reinforce the regional competitiveness, development and social cohesion. The increase in ICT use not only brings about benefits to all aspects of socio-economic activities but also enhances the marketing and imaging of small or medium sized societies (Castells, 1997). The benefits concern the competitiveness and innovation of businesses (development of new software and electronic commerce and services), education (PC use in schools with internet access, teleeducation), employment (ICT use in the labor market, telecommuting), healthcare (lab equipment, tele-medicine), environment (prevention of natural disasters, measurement of environmental pollution, scheduling and monitoring of renewable energy resource projects), accessibility (Intelligent Transport Systems) and public governance (electronic processes in bureaucratic matters etc.). Intelligent Transport Systems (ITS) refer to a wide range of applications of ICTs into all categories of the transport sector.

On the other hand, the literature (Malecki and Moriset, 2008) has shown that ICT-enabled access to labor pools in remote areas cannot provide per se a model of sustainable development. Due to the co-existence of various centrifugal and centripetal forces which drive businesses to relocate and reorganize their processes in the digital economy, misallocation of investments in ICT infrastructure and services may amplify spatial inequalities in their use (the problem of digital gap or digital divide). Hence, other factors that can decisively influence these forces, such as conditions of physical accessibility and natural advantages within a region, should be jointly taken into account for the planning and evaluation of infrastructure investment programs. In the existing literature, the analysis of the geographical characterisitcs of the digital divide has generally focused on the level of countries; research at 
the regional level is much scarcer (e.g. Vicente and López, 2011) and mostly refers to the United States.

Specifically regarding the ITS technologies, they aim at improving the efficiency and reducing the external costs of transport systems. Their deployment can diminish accident risk and environmental pollution, and increase the level of service and reliability, in order to promote firm benefits and users' satisfaction. ITS can also be used for the management of travel demand for private or public transport modes, especially for medium- and long-distance travel, and, to some extent, for the relaxation of the dependence of consumers on motorized transport. The benefits from the management of transport and reduction of travel-related energy and environmental costs can support the sustainable local development of remote regions and territorial cohesion (Grimes, 2000; Cohen et al., 2002). Such systems allow the timely information provided to users, indicating them, for example, the optimum route and describing the (future) traffic conditions and arrival time by car, bus or train. Also, they facilitate the management of infrastructure and the efficient monitoring and control of traffic flows in transport networks (Giannopoulos, 2004). They additionally offer smart payment services for the use of transport facilities, e.g., through "intelligent" cards and electronic ticket payment and reservation of parking places (Jakubauskas, 2006).

Furthermore, ITS can offer timely and efficient emergency management by helping to take remedy measures, in such cases as the closure of routes due to non-recurrent congestion problems (Ozbay and Kachroo, 1999), evacuation and special events, vehicle damage, excessive travel speed, violation of safety rules and vehicle or cargo theft (Jarašūnienè and Jakubauskas, 2007). Besides, they can contribute to the optimization of the operational and financial management of networks and facilities, e.g. via the real-time sensor surveillance of the status of liquid cargo, liquid tanks and cooling warehouses, and the advanced administration of customs, immigration, police and health services (Zografos and Regan, 2004; Caris et al., 2008; Boschian et al., 2012). The application of such - more elaborate and intelligent - services can highly assist in the achievement of certain goals of the European and national policy concerning the safety, efficiency and reliability of the passenger and freight transport system. Both public and private investments in this direction are expected to have important benefits for the strengthening of regional competitiveness across the country and the improvement of services, especially in transport and tourism. 
By employing an exploratory data analysis and simple statistical measures and correlations (Section 4), the paper aims at demonstrating the various interrelationships and interdependencies pertaining to the spatial development of transport and ICT infrastructures and services in the Greek regions. It shows how the recent advances in the adoption of and accessibility to digital technologies, through considerable public and private investment projects, can potentially enhance the conditions of establishing or expanding the deployment of ITS. In turn, it describes how the ongoing institutional arrangements about the ITS and the decentralization of transport investments can help the expansion of ITS at the regional-scale and, hence, the reduction of the digital gap in the peripheral areas. The paper advocates an integrated investment policy for the enhancement of both the digital and physical accessibility throughout the country.

As far as the organization of the rest of the paper is concerned, Section 1 presents the requirements for digital convergence and the ICT infrastructures in Greece. Section 2 describes the framework underlying the current development of ITS in the country and Section 3 refers to major applications of transport telematics in Greek cities and peripheries. Section 4 analyzes and discusses the allocation of investment expenditure for Intelligent Transport, Information Society and transport infrastructure by category across the Greek regions/prefectures. Last, the section of Conclusions summarizes and provides implications for designing an integrated investment policy to strengthen both the digital convergence and physical accessibility.

\section{Digital Convergence and ICT Infrastructures}

This section sets out a number of indicators related to the usage of PCs and internet from households and businesses at the regional level, which depict the current situation of digital accessibility and the problem of digital gap. Then, it describes the typology of ICT infrastructures and services, the criteria and market conditions in which the development of ICTs has taken place, and how the deployment of these technologies can be associated with the process of digital convergence in Greece. The Operational Program "Information Society" in the $3^{\text {rd }}$ Community Support Framework (CSF) $2000-2006$, as well as the one called "Digital Convergence" in the following National Strategic Reference Framework (NSRF) 2007-2013, primarily aim at strengthening the developmental impacts of ICTs. 
The use of ICT infrastructure is closely related to the competitiveness of the Greek Regions, once it supports and enforces the knowledge society, knowledge externalities and the productivity of business sectors which are exposed to the national and international competition. The positive contribution of the ICTs on the productivity growth in Greece has been identified in several studies, both at the national and industry levels (Terrovitis, 2005; Antonopoulos and Sakellaris, 2009; Papaioannou and Dimelis, 2011), as well as the individual firm level (Arvanitis and Loukis, 2009).

Aside from being national-oriented, the ICT investments maintain a major transnational orientation as well. This is because they promote the international cooperation and the competitive role of Greece in the wider area of Southeastern Europe. Consequently, the development of synergies among the investments of the NSRF and other funding sources for digital convergence and the development of Trans-European telecommunication networks as well as other programs are considered of great importance. Specifically, the promotion of the project SEELight (South-East European Lambda Network Facility for Research and Education), which is part of the Greek Plan for Economic Reform in the Balkan Countries (GPERB), for the development of high-speed optical fibre network in Balkans will upgrade the quality of and further expand the national ICT infrastructure (Tsekeris et al., 2011).

The role of managerial aspects of European transport policy, through the application of ITS, has been largely underestimated in the past years (Peters, 2003). However, the adoption of ICTs attracts an increasing attention for addressing issues of network connectivity and interoperability, congestion mitigation, regional development and territorial cohesion. In particular, the recently (as of 2011) launched funding plan of the European Commission titled "Connecting Europe" aims at creating common investment mechanisms to develop transport, energy and ICT infrastructure networks, especially at cross-border peripheries and bottleneck areas. Such coordinated investments can help to create interconnected corridors (e.g., of highspeed train, energy pipeline and super-fast broadband optical fibre networks), which will promote the efficient movement of passengers, energy loads and information flows with increased reliability, environmental sustainability and reduced investment risk.

Table 1 presents the percentages of PC use and internet use (among the PC users) from households and the percentages of PC use, Local Area Network (LAN) use and internet use (among the PC users) from businesses, per Region (NUTS-II level), for the year 2008 (see 
also OIS, 2009b). The level of ICT use constitutes a determinant factor for the creation of a "critical mass" in the population which will allow the penetration and adoption of ITS from households and businesses (Nijkamp et al., 1996). The promotion of ICT use relies on the development of ICT infrastructures (cables, clusters, available ADSL lines, third generation broadband networks etc.), which are described later in this section, to ensure the creation of the necessary productivity conditions (Zavadskas et al., 2010).

Table 1 - Percentage of PC and internet use from households and businesses per Region (2008) ${ }^{1}$

\begin{tabular}{|c|c|c|c|c|c|c|c|c|c|c|}
\hline Region & \begin{tabular}{|c} 
PC use \\
Percentage of \\
private owners \\
- households
\end{tabular} & $\begin{array}{c}\text { Comparative } \\
\text { percentage to } \\
\text { Attica }\end{array}$ & $\begin{array}{c}\text { Intrnet use } \\
\text { Percentage of } \\
\text { private owners } \\
\text { - households }\end{array}$ & $\begin{array}{c}\text { Comparative } \\
\text { percentage to } \\
\text { Attica }\end{array}$ & $\begin{array}{c}\text { PC use } \\
\text { Percentage of } \\
\text { businesses }\end{array}$ & $\begin{array}{c}\text { Comparative } \\
\text { percentage to } \\
\text { Attica }\end{array}$ & $\begin{array}{c}\text { LAN use } \\
\text { Percentage of } \\
\text { businesses }\end{array}$ & $\begin{array}{c}\text { Comparative } \\
\text { percentage to } \\
\text { Attica }\end{array}$ & $\begin{array}{c}\text { Internet use } \\
\text { Percentage of } \\
\text { businesses }\end{array}$ & $\begin{array}{c}\text { Comparative } \\
\text { percentage to } \\
\text { Attica }\end{array}$ \\
\hline East Macedonia \& Thrace & 39.00 & 68.06 & 39.40 & 69.12 & 77.80 & 83.21 & 33.20 & 45.67 & 68.60 & 74.89 \\
\hline Attica & 57.30 & 100.00 & 57.00 & 100.00 & 93.50 & 100.00 & 72.70 & 100 & 91.60 & 100.00 \\
\hline North Aegean & 41.70 & 72.77 & 41.90 & 73.51 & 85.00 & 90.91 & 67.70 & 93.12 & 85.00 & 92.79 \\
\hline West Greece & 39.00 & 68.06 & 38.80 & 68.07 & 88.00 & 94.12 & 70.10 & 96.42 & 88.00 & 96.07 \\
\hline West Macedonia & 31.30 & 54.62 & 32.80 & 57.54 & 78.10 & 83.53 & 39.70 & 54.61 & 75.90 & 82.86 \\
\hline Epirus & 31.40 & 54.80 & 32.20 & 56.49 & 78.90 & 84.39 & 54.80 & 75.38 & 76.70 & 83.73 \\
\hline Thessaly & 29.60 & 51.66 & 28.40 & 49.82 & 84.80 & 90.70 & 54.30 & 74.69 & 64.30 & 70.20 \\
\hline Ionian Islands & 41.60 & 72.60 & 37.00 & 64.91 & 77.70 & 83.10 & 55.80 & 76.75 & 77.70 & 84.83 \\
\hline Central Macedonia & 42.40 & 74.00 & 41.30 & 72.46 & 87.00 & 93.05 & 37.50 & 51.58 & 82.00 & 89.52 \\
\hline Crete & 44.60 & 77.84 & 43.80 & 76.84 & 76.40 & 81.71 & 30.40 & 41.82 & 62.50 & 68.23 \\
\hline South Aegean & 45.40 & 79.23 & 47.20 & 82.81 & 91.90 & 98.29 & 73.60 & 101.24 & 91.90 & 100.33 \\
\hline Peloponnese & 33.60 & 58.64 & 34.60 & 60.70 & 77.90 & 83.32 & 53.60 & 73.73 & 68.70 & 75.00 \\
\hline Central Greece & 36.20 & 63.18 & 36.50 & 64.04 & 75.30 & 80.53 & 36.60 & 50.34 & 71.50 & 78.06 \\
\hline Whole country & 43.90 & 76.61 & 43.50 & 76.32 & 88.00 & 94.12 & 59.00 & 81.16 & 83.60 & 91.27 \\
\hline
\end{tabular}

Aside from the absolute proportions of ICT use, comparative proportions are also presented for each Region with respect to the Attica (the base Region, where the capital city of Athens is located). These data provide insight into the regional digital gap in the country. Specifically, the data allow a classification of the Regions, depending on the level to which they have a short fall in comparison to Attica, which displays the higher levels of ICT use in most indicators. Namely, the knowledge economy is geographically concentrated mostly in the metropolitan area of Athens, which acquires a comparative advantage against the other Regions of the country. The Regions with the smaller percentages $(<60 \%)$, in comparison to Attica, concerning PC and internet use are West Macedonia, Epirus, Thessaly and Peloponnese (only in relation to the PC use).

Regarding the businesses, the digital gap does not seem to be that wide in comparison to households. A relatively high percentage ( $81 \%$, on average) is observed in the use of LANs

\footnotetext{
${ }^{1}$ Source: Own-processing of data from the Observatory for the Information Society, Greece.
} 
and, particularly, of PCs (94\%, on average) and internet (91\%, on average) in the businesses of the rest Regions, in comparison to the base percentage (100\%) in the Attica Region. Moreover, regarding the LAN and internet use, in 2008, one might observe higher percentages in the South Aegean than in Attica. This fact probably reflects the dependence and greater focus that is given by local businesses (especially in the field of tourism) on digital technologies for the development of their activities and customer services.

Concerning the development of ICT infrastructure in Greece, during the last few years (for a relative review see EU, 2009), a large number of projects were only just recently completed. It is indicatively mentioned the completion of a large-scale broadband optical fibre network in Northern Greece (in the prefectures of Grevena, Pella, Kastoria, Kozani, Florina and Imathia) from CYTA (Subsidiary of the National Telecommunications Organization of Cyprus). The construction of metropolitan broadband optical fibre networks is still in progress, under the NSRF, with the aim to connect more than 3.000 areas of public interest (universities, museums, libraries, etc.) as well as provide fast and cheap internet access to users. The development of these networks is considered as particularly important for the (semi-)rural areas of the country. It is estimated that broadband lines have been increased by $507 \%$ (1.506.614) after the voting of the new telecommunication law (no. 3431) in 2006. Nevertheless, although the coverage of DSL technology in urban areas peaked at $100 \%$ during 2009 , the same technology coverage in rural areas was just increased to $50 \%$.

As far as the infrastructure of telephone companies is concerned, these have demonstrated a major development, with the purpose of creating innovative and advanced services. More specifically, COSMOTE (subsidiary of the Greek Telecommunication Organisation - OTE) recently upgraded the $3 \mathrm{G}$ network by utilizing HSDPA (High Speed Downlink Packet Access) technology, in order to provide mobile ADSL speed up to 7,2 Mbps. The broadband network for mobile phones of the company is the largest in Greece, with 3G coverage for almost the $85 \%$ of the Greek population. HOL company offers a wider private network of optical fibres - following OTE - which expands over $3.800 \mathrm{~km}$ in Greece. The company's services are available in 50 prefectures and 140 cities, covering the most isolated areas of Greece. Tellas company owns an optical cable land network of $700 \mathrm{~km}$ length, in the following main routes: Athens - Corinth - Argos - Tripolis - Kalamata, Patra - Pyrgos Megalopoli, Tripoli - Sparta and Chania - Rethymno. The network is completed with the 
underwater optical fibres between Nafplio-Chania (of $255 \mathrm{~km}$ length) and Rio-Antirrio (of 4 km length).

Furthermore, the international underwater network of optical fibre connection is also in operation, owned by the Italian company Wind, which is to be connected with the network of ORASCOM Telecom in Cairo. Forthnet company offers cable networks for the international interconnection of the country through optic fibres of a total capacity of 33 Gbps (18 Gbps from Athens and $15 \mathrm{Gbps}$ from Thessaloniki). Vivodi Telecom has realized an international high-capacity network consisting of multiple circuits and interconnections, including more than 30 international telecommunication agencies. The company's network achieves high capacities, through DSL technology, which is supported by the main network, consisting mostly of microwave connections of high capacity and of national and international circuits of optic fibres.

The third generation broadband technology, that all mobile phone companies develop, offers double-play and triple-play services, which include home and cell phone as well as broadband access to the internet. This notable expansion (mostly above the European average) is indicative of the Greek broadband market, since the penetration of broadband services was increased to $13.4 \%$ in January of 2009 or by $9.1 \%$ per year. Greece is one of the countries which display a major penetration of cell phone well above the European average (122\% against $119 \%$ in 2008), with a total of 13.708 .972 subscriptions in October 2008. The development of network infrastructures for public governance concerns a main access network for Public agencies, with the aim to cover all the needs for internal phone communication and data exchange (computer communication - internet, video). Particularly, GUNet network refers to the development, support and administration of the academic network of all Greek Universities, offering networking services for both academic and research purposes.

Nevertheless, there is a lack of alternative digital networks, since Greece is the only EU country with zero percentage of broadband lines provided by technologies other than DSL. The need for developing wi-fi broadband access points in remote areas of the country is also evident. In a nutshell, the vast development of broadband networks from private phone companies in Greece is mainly associated with business (efficiency) - and not social (equity) - criteria. Namely, the phone companies offer internet access and focus on the continuous 
improvement of efficiency indicators for the invested capital, thus neglecting requirements for the geographically balanced use of such services.

\section{ITS Development Framework in Greece}

In the last two decades, ITS have created a rapidly developing market in the transport sector. Their primary objective lies on treating negative externalities in transport, thus allowing the more efficient use of transport infrastructure and services. These systems first appeared in 1970s, with initial purpose the efficient circulation of road vehicles, through systems of automated traffic signalling. In the course of time, the rapid technological progress, emphasis on free market economy and internationalization of trade and services led to the diffusion of ITS to a wide range of services in transport, as well as in other related activities (Wiegmans et al., 2003; EAITI, 2007). Among other things, these activities include the management of transport demand, traffic, infrastructure, environment and energy resources.

The institutional framework which conditions the transport telematics market is subject to an ongoing reform, especially with the development of private business initiatives across the world, like in Greece, for the provision of digital information systems to the public in a personalized way. Such initiatives are supported by co-funded European programs, as well as public authorities. In Greece, the main information sources which feed the smooth functioning of ITS are the public transport timetables and road traffic data, measured by state-owned and operated detectors for the network of Athens. The institutional framework allows the selling of such data to individuals. Nevertheless, this type of information is freely supplied (as public good) in most countries, taking into consideration its major positive impact on both improving the network efficiency and the environment. Such an effect stems from the further processing and supply of this information to passengers, carriers and other stakeholders.

Furthermore, the private-sector initiatives are expected to enrich both the amount and quality of the available traffic data, via new sources of data collection, and enhance their accessibility from different types of users. Such information sources refer to fleets of floating vehicles, for example, fleet of taxi vehicles equipped with location detection devices, such as the ones based on the satellite detection systems of Global Positioning System (GPS) and Global Navigation Satellite System (GNSS). In such a way, data are constantly stored keeping 
records of the vehicles' position in the network as well as their movement characteristics, such as distance traveled, speed, and travel time across certain routes and are transmitted in real time conditions to the central traffic management centre.

The market-orientated framework of ITS development encourages the innovation and competition among companies, contributes to the improvement of the existing technological infrastructure and promotes the differentiation of the ICT products (offered services) as well as of their prices for the benefit of consumers. The product differentiation comes from the ITS development due to different information sources which can be directed to various types of users, such as privately owned vehicle drivers, public transport passengers and operators and commercial firms from different sectors willing to pay more in order to experience higher precision and reliable services.

For instance, the information and navigation services offered to firms transporting dangerous materials can be more highly charged, due to their increased demand (for risk aversion). On the other hand, services which offer other types of transport and storage services can be charged with a lower rate, depending on the level of congestion, environmental factors etc (Stathopoulos and Tsekeris, 2009). The market-orientated development of such initiatives is the core objective of national and European non-profit organizations in the field, such as the ITS-Hellas, which was founded in 2008 to provide a national platform for implementing and evaluating new telematics applications in the transport sector, and ERTICO (European Road Transport Telematics Implementation Co-ordination Organization), which was founded in 1991 to promote new transport technologies of the Information Society at the European level.

In the face of the growing restrictions to state funding, investment initiatives in this field may even come from the self-funding of ITS, through concession schemes or Public-Private Partnerships (PPPs), with the participation of private-sector companies from different areas, such as tourism organizations and car industries familiar with ITS services. Such schemes can help the ITS market to cover emerging needs of customers and wider geographical areas, especially those of the countryside and the islands. The development of value added specialized services can be taken up from private-sector companies whereas the public sector can remain responsible for the development of the basic infrastructure for collection, processing and supply (free or for sale) of information. 
In this framework, PPPs must be focused more on offering services and not infrastructure development as they normally do. This is because the approaches for the socio-economic evaluation of ITS investments should be different than those normally adopted for assessing the returns of road, rail or other physical infrastructure investments (Banister and ThurstainGoodwin, 2011). Since the deployment of ITS is pertaining to uncertainty and is influenced by a number of random factors, probabilistic approaches and simulation methods are required for the comprehensive evaluation and risk assessment of their operation (Khan, 2009; Stathopoulos and Tsekeris, 2009; Baublys and Jarašūnienè, 2010).

It is noted that although there is a long-standing and well-documented evidence of the impacts of transport infrastructure investments on the spatial and economic development of a region/country (Banister and Berechman, 2003), such evidence for the case of ITS investments is still quite limited (Soekkha, 1990; Ioannides et al., 2008). Last, the public sector or a responsible regulatory body must set the rules which will ensure the development of an open interconnected architecture for the smooth completion and integration of ITS (existing and planned) at national and European scale. In this way, a harmonic cooperation among all the involved agencies and stakeholders can be ensured during the whole lifecycle of the project.

\section{ITS Applications in Greek Cities and Peripheries}

In Greece, the development of transport telematics presents a constant progress, although relative penetration levels have not reached those of other EU countries (e.g., U.K., Germany, France) (see Grimes and Collins, 2002; Jarašūnienè, 2006) and especially the U.S.A. In general, such systems cannot be considered as part of the everyday decision-making process for most network users. Recently, major investments have taken place with regard to physical and technological infrastructures. Nevertheless, Greece still lacks the ability to further exploit the resulting capabilities available. The main applications of ITS programs focus on the large urban centers of Athens and Thessaloniki. Also, they concentrate on major highway corridors, especially those operating under PPP schemes. On the contrary, there is a serious lack of such initiatives in other types of infrastructure (railways, airports and seaports) and areas of low transport demand, such as the rural areas and islands. The participation of these areas in the broadband digital networks still remains limited. 
In particular, there are limited ITS applications in the field of public passenger transport apart from the urban transport in the areas of Athens and Thessaloniki. These specific applications include dynamic route information and navigation systems, such as the dynamic traffic map in Athens (Stathopoulos and Tsekeris, 2008), changeable message signs and information systems for road and public transport passengers (tram, metro, suburban rail). Also, the Urban Transport Organization of Thessaloniki (UTOT) implements an advanced communication and management system for the bus fleet. As for the rest of the cities, after 2007, several initiatives have been implemented by local urban bus companies (KTEL), the Panhellenic Federation of Urban Transport, and Local Authorities, supported by the central government, for the introduction of electronic payment and passenger information systems as well as bus fleet management systems. Indicative examples of such initiatives is the implementation of ITS into the regional collaborative trip planning in the island of Chios (Sigala 2010) and the urban public transport system of the city of Trikala, in the context of the E-TRIKALA program (Mizaras, 2008).

Such ITS deployments, possibly in conjunction with urban traffic and parking management systems, are expected to raise passenger demand for local bus services, improve the level of service and reduce operating costs. The use of electronic charging and toll payment systems is particularly important for the management of transport infrastructure (Tsekeris and Voss, 2009) and it is currently applied into the Athens ring road (Attiki Odos), as well as the national roads. In the future, such systems can facilitate the urban-scale deployment of road user charging strategies, such as urban cordon pricing and area-wide congestion charging. In addition, the adoption of ITS for the operational management of emergencies allow the information dissemination to services, such as the police, road assistance, ambulances, firefight units, in order to achieve timely intervention and save valuable time. Other logisticsoriented applications of ITS include the product cost allocation and supply service pricing per vehicle, customer, route and delivery point, and the overall evaluation of firm efficiency.

\section{Regional Investment Allocation for Intelligent Transport}

In the 3rd CSF, ITS were funded through the expenses of the applications of the Information Society program in transport. The expenses of that program included investments in Greek ITS infrastructures. In the NSRF, this category of expenses is included in the corresponding 
"Digital Convergence" program. Table 2 shows the 3rd CSF expenses for several types/categories of transport-related projects throughout Greece between 2000 and 2009, which is the last year with available data in the course of this study. These project types refer to roads, railways, seaports, airports, urban transport (public mass transit), transport safety and Information Society (telematics) applications in transport. Investments from the Information Society program in transport, namely, Intelligent Transport Systems, cover only a very small percentage $(0.3 \%)$ of the total investments (at the prefecture, NUTS-III level) for transport. Road projects take hold of the greatest percentage (65.7\%) while railway projects follow with $19.2 \%$, urban transit reach up to $6.0 \%$, seaport projects to $4.6 \%$, airports to $2.7 \%$ and transport safety projects up to $1.6 \%$.

Table 2 - Time Public expenses (in current prices in millions $€$ ) of the $3^{\text {rd }}$ CSF for transport projects $(2000-2009)^{2}$

\begin{tabular}{|c|c|c|c|c|c|c|c|c|c|c|c|c|c|}
\hline $\begin{array}{l}\text { Project } \\
\text { Category }\end{array}$ & 2000 & 2001 & 2002 & 2003 & 2004 & 2005 & 2006 & 2007 & 2008 & 2009 & Total & $\%$ & $\begin{array}{c}\text { Correlation } \\
\text { with ITS }\end{array}$ \\
\hline Roads & 221.88 & 430.57 & 624.58 & 779.91 & 515.93 & 573.21 & 761.14 & 1006.69 & 1103.11 & 842.58 & 6859.60 & 65.66 & $0.813^{*}$ \\
\hline Railways & 2.38 & 63.44 & 159.08 & 132.37 & 115.32 & 70.85 & 185.50 & 430.77 & 433.20 & 409.39 & 2002.30 & 19.17 & $0.810^{*}$ \\
\hline Seaports & 7.05 & 17.15 & 25.96 & 33.36 & 45.64 & 59.57 & 66.74 & 71.36 & 81.31 & 75.19 & 483.32 & 4.63 & $0.770 *$ \\
\hline Airports & 7.85 & 18.59 & 33.99 & 49.41 & 51.25 & 19.19 & 21.30 & 17.10 & 33.33 & 24.96 & 276.97 & 2.65 & -0.187 \\
\hline $\begin{array}{l}\text { Urban } \\
\text { Transit }\end{array}$ & 0.18 & 1.20 & 49.97 & 137.09 & 204.60 & 81.73 & 18.81 & 22.90 & 31.22 & 78.57 & 626.26 & 5.99 & -0.341 \\
\hline $\begin{array}{l}\text { Transport } \\
\text { Safety }\end{array}$ & 0.00 & 0.29 & 26.38 & 32.80 & 41.89 & 15.58 & 1.65 & 8.59 & 9.91 & 29.09 & 166.17 & 1.59 & -0.336 \\
\hline ITS & 0.00 & 0.00 & 0.00 & 0.00 & 0.04 & 2.52 & 4.78 & 10.75 & 11.60 & 2.69 & 32.37 & 0.31 & 1.000 \\
\hline
\end{tabular}

More specifically, as far as the Information Society program expenses in the transport sector are concerned, a rapid increase is observed from 0.04 million $€$ in 2004 to 11.6 million $€$ in 2008, while a reduction to 2.7 million $€$ is observed in 2009. Furthermore, Table 2 shows the Pearson's correlation coefficient, $r(\%)$, between the annual Information Society expenses in transport and the annual expenses in other types of transport projects for the study period (last column of Table 2). Note that the Pearson's coefficient measures pairwise correlation between two variables. Namely, it does not take into account the multivariate structure of the problem,

\footnotetext{
${ }^{2}$ Source: Own-processing of data from the General Secretariat of Investments and Development, Ministry of Economy and Finance, Greece. Note: $\left(^{*}\right)$ indicates statistically significant correlation at the $99 \%$ level of confidence (p-value<0.01).
} 
like, for example, a multiple regression approach. Other potential variables which may be associated with Information Society expenses are the investment in Research and Development (R\&D) projects, agglomeration economies, the level of economic development and the production structure in each region, the market structure of firms and political factors. The results show that there is a high $(r=81.3 \%)$ and statistically significant (at the 99\% level of confidence) correlation between the Information Society expenses in transport and road expenditure. High and statistically significant (at the $99 \%$ level of confidence) correlations are also observed between the ITS expenditure and railway and seaport expenditures $(r=81 \%$ and $r=77 \%$, respectively). The geographical diffusion of transport expenditure from the Information Society program can be considered as limited, once the main ITS infrastructure investments are mostly concentrated on the metropolitan areas of Athens and Thessaloniki (Section 3).

By analyzing the percentage distribution of the Information Society program expenses in transport per prefecture (NUTS-III) level (Figure 1), we notice that in the Attica and Thessaloniki, expenditure reaches up to $38 \%$, which is more than the $1 / 3$ of the total Information Society program expenses in the transport sector. Larisa follows with $10.3 \%$, Kavala with $6.5 \%$, Lesvos with 6.3\%, Dodecanese with 5.2\%, Ilia with 5\% and Preveza with $5 \%$. Figure 2 displays the percentage distribution of the expenditures from the $3^{\text {rd }} \mathrm{CSF}$ Information Society program in various fields/sectors of the economy. It is noticed that transport takes hold of only a small percentage (3.5\%) of the total Information Society expenses.

The largest portions correspond to the fields of public governance (32.3\%), education (16.6\%), communication (15.7\%), culture and tourism (9.6\%), research and technology (9.2\%), and health and welfare (5.6\%). The small percentage of the expenses that are allocated to ITS is indicative of the relatively limited role played by the transport sector in the strategic development of ICTs in Greece. More specifically, the digital strategy mostly focuses on upgrading the quality of life (almost $50 \%$ is distributed among public governance and education), rather than on promoting territorial development, e.g., through ICT investments in transport infrastructure. 


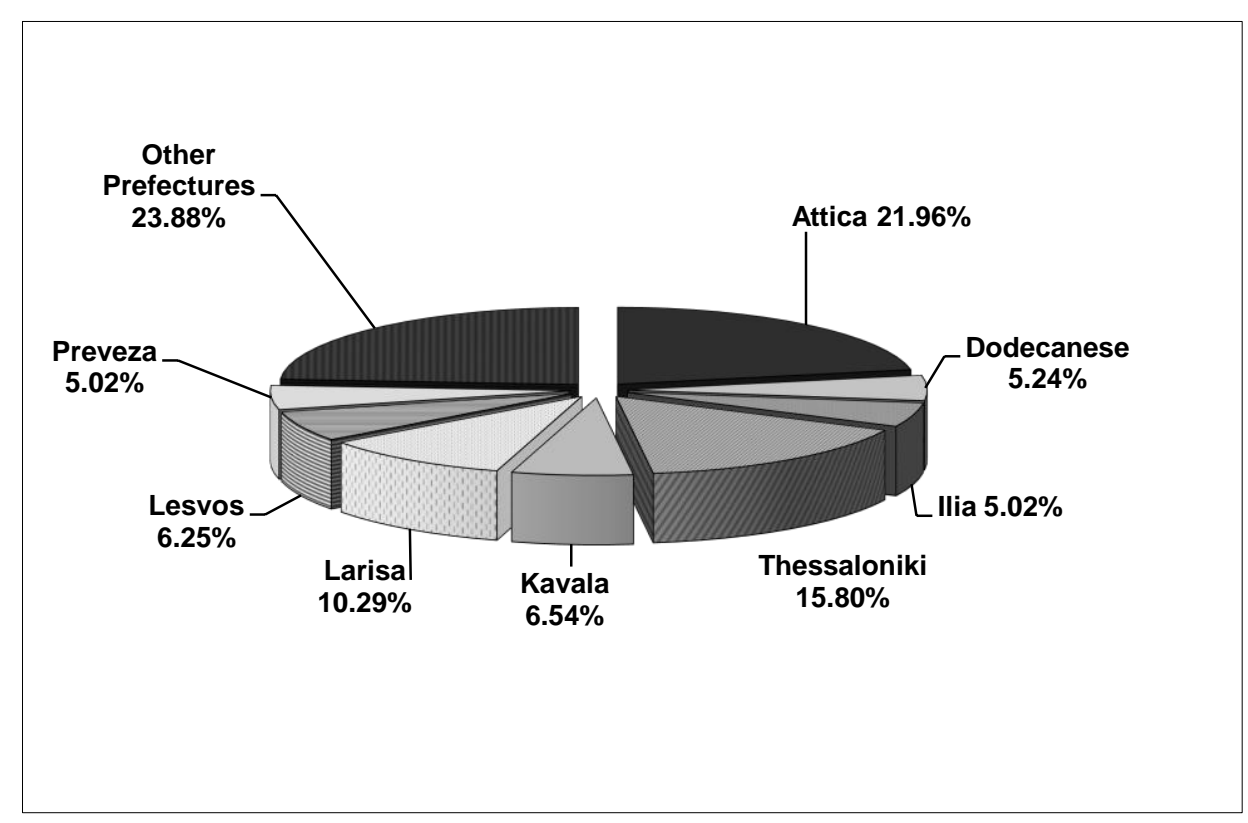

Figure 1: Spatial distribution (\%) of the $3^{\text {rd }}$ CSF Information Society expenditure in transport at the prefecture level (2000-2009) ${ }^{3}$

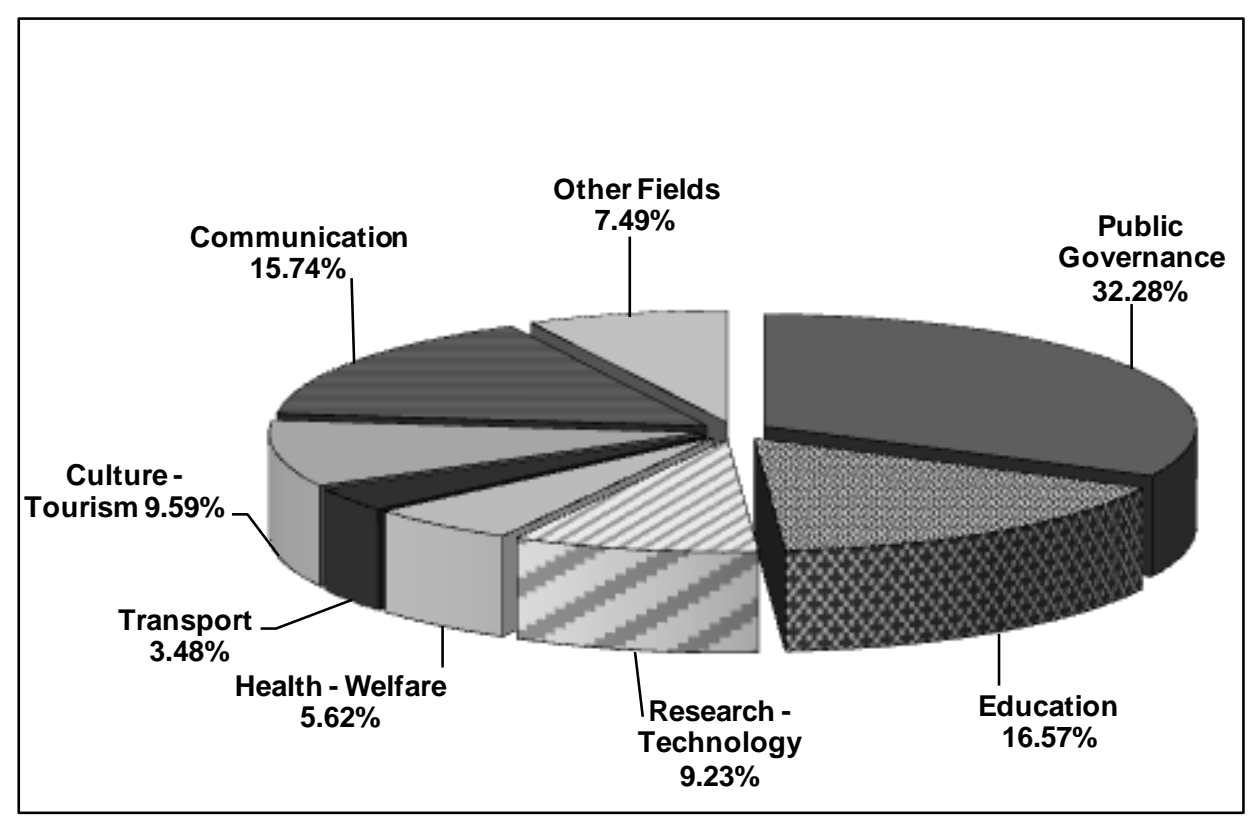

Figure 2: Spatial distribution (\%) of the $3^{\text {rd }}$ CSF expenditure in different fields of the Information Society $(2000-2009)^{4}$

\footnotetext{
${ }^{3}$ Source: Own-processing of data from the General Secretariat of Investments and Development, Ministry of Economy and Finance, Greece.

${ }^{4}$ Idem.
} 
By and large, these results stress the relatively narrow developmental perspective of ITS in public investments throughout Greece and the limited impact of transport on regional digital convergence. During the 2000 decade, the increased expenses for road projects (see Figure 1) were neither followed by the achievement of a large proportion of Information Society program spending for transport nor by a large diffusion of ICTs across remote regions, in comparison with the two main metropolitan areas. Figure 3 displays the spatial distribution of the $3^{\text {rd }}$ CSF expenditures for road projects per prefecture in the period spanning 2000-2009. Only a relatively small expenditure percentage (almost 15\%) (in relation to the population) is totally distributed among the prefectures of Attica and Thessaloniki for roads. Most of the expenditures in road projects concern other regions, such as Ioannina (11.7\%) and Grevena (8.3\%) (mainly, due to the Egnatia highway), and Fthiotida (7.6\%).

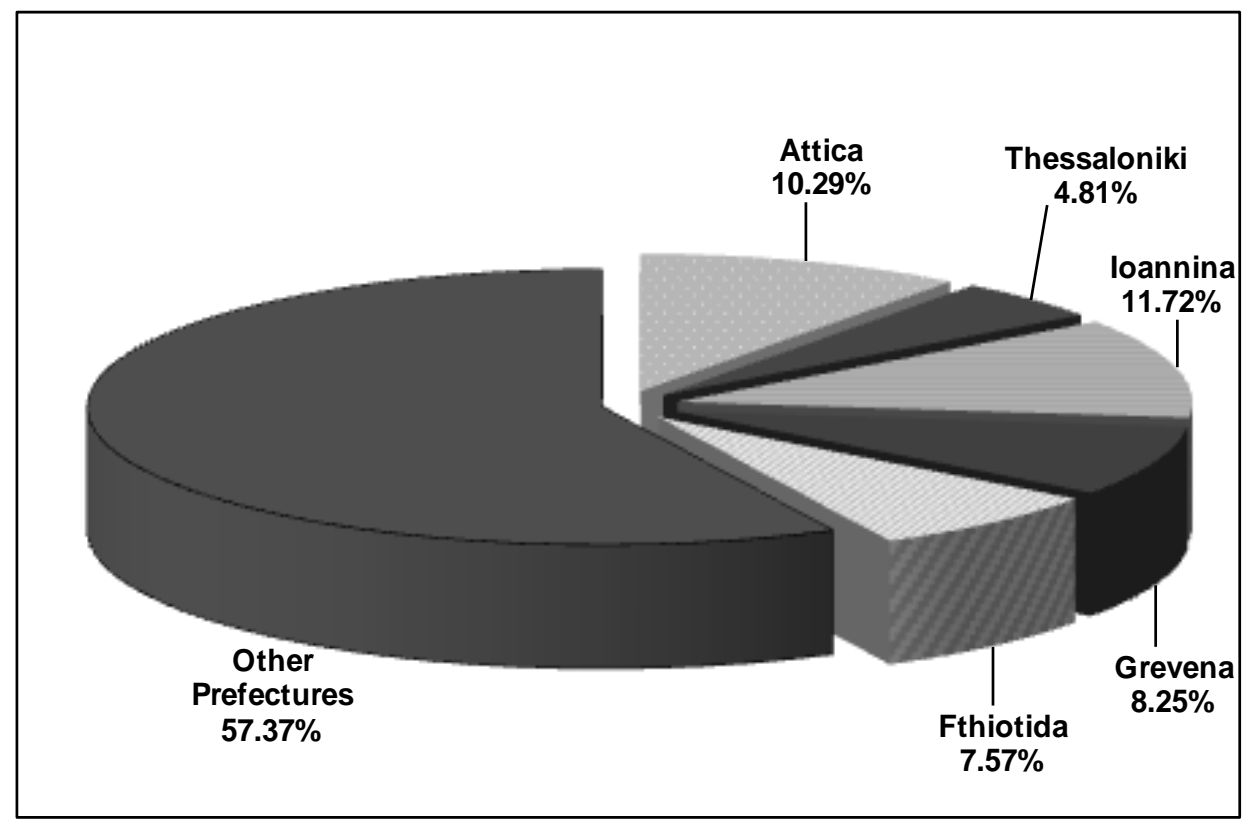

Figure 3: Spatial distribution of the $3^{\text {rd }}$ CSF expenditure in roads at the prefecture level (2000-2009) $)^{5}$

Public expenses for roads in the peripheral regions are not complementary with ITS investments (or do not provide the opportunities for major synergies). Consequently, this increased road investment activity should be combined with ITS investments targeted at rural or semi-rural areas (rural ITS). Such systems focus on long-distance transport or local transport in low-density or underpopulated areas ( $<50$ thousand habitants) across the regional and national road network. These ITS address the individual needs and priorities of rural and

\footnotetext{
${ }^{5}$ Source: Own-processing of data from the General Secretariat of Investments and Development, Ministry of Economy and Finance, Greece.
} 
tourist/resort areas through information systems connected with tourism, weather conditions, accident risk, health, crisis management services etc. In this way, the procedure of expanding broadband networks in every spot of the Greek periphery (digital convergence) will be accelerated, the external transport cost will be reduced and the sustainable regional development will be enhanced.

Simultaneously, more investments in public transport for the upgrading and modernization of regional airports, seaports, railway network, urban and interurban bus fleets (KTEL) and the combined or multimodal transport infrastructure (freight centers, transit terminals etc.) become a prerequisite for the regional expansion of ICTs. ITS can greatly contribute to the effective allocation and management of such investments, through promoting the safety, security and quality of the transport infrastructure and services, and the convergence of economically disadvantaged regions of the country.

\section{Conclusion}

This paper investigated the spatial investment patterns and activities in the sectors of transport and ICTs, and their implications for regional digital convergence in Greece. Specific emphasis was given in identifying the relations: a) of the capability of the use of ICTs and the modal investments in the transport sector, and b) of the digital and physical accessibility in the country. The findings emphasize the need for designing a comprehensive regional investment and evaluation policy for strengthening both the digital and physical accessibility in the peripheral areas of a country. This policy should address strategic interactions emerging in the various life-cycle phases of different types of (transport, ICT and other) infrastructure projects. A complete institutional/regulatory framework and the appropriate technical requirements should be designated to ensure the operation of an open interconnected architecture that will integrate current and future ITS at national and European scale. In this way, ITS projects will not be treated only as local-scale and operationally isolated infrastructures, but their deployment will take into account their region-wide compatibility and complementarity among each other.

The fiscal decentralization, coordination and, possibly, cross-subsidization of different types of infrastructure projects will support the development of an extended multimodal transport 
network which will facilitate and exploit most of the peripheral investments in ICTs. In Greece, the growing private investment initiatives and the relative increase of public investments for digital convergence, through the current NSRF, in underpopulated and remote (mountainous and island) regions is expected to reinforce the coupling between the digital and physical infrastructure in the transport sector. In particular, the ICT-related transport infrastructures and services can support the management of travel demand needs (Salomon, 1986; Mokhtarian, 1990; Banister and Stead, 2004), including the reduction of travel where there are feasible alternatives, and the more cost-effective, environmentally viable and energy-efficient motorized transport of households and firms.

Other ICT investments, such as those related to telecommuting, tele-education and telemanagement of business operations, can be used to develop existing human capital and maintain or create new employment positions in peripheral areas, through promoting knowledge spillovers, social interaction and learning processes. Both the transport- and nontransport-related ICTs can enhance agglomeration economies, produce additional flows of tourists and encourage the location of new businesses in the Greek periphery. Hence, they can contribute to the expansion of economic activities, including regional innovation centres, and growth of local business productivity and competitiveness. Consequently, ICTs and, especially, ITS deployment can enhance the sustainable regional development and address issues of territorial isolation/exclusion and unemployment.

The spatial expansion and decentralization of the (passenger and freight) transport network and traffic flows in Greece will lead to increased accessibility and accumulation of more investments for ICT infrastructure in the periphery. In turn, these actions will help to bridge the digital gap between the economically disadvantaged regions, at both the national and European level, by increasing broadband network connections, creating new opportunities for electronic commercial activities and public e-transactions, thus upgrading the quality of life. Nevertheless, the planning of ITS should take into consideration the individualized demand needs of users in remote regions, in accordance with the accessibility, weather and other special conditions prevailing in each target area.

Moreover, the ITS should be combined with suitable policies for traffic management (e.g., for saving parking space, prioritizing public transport modes, and managing the movement of trucks for the goods distribution and pickup), mechanisms for charging the use of transport 
facilities, and investment in new and maintenance of existing infrastructures. Such an integrated approach is able to gradually affect the modal preferences of users, in terms of public transport modes, so that the desired benefits will be achieved and sustained in the long run. Finally, the investments for digital convergence will reinforce the system of public electronic governance at a central and regional level, and they will advance the prerequisites for the dynamic ITS market development across the country.

\section{References}

Antonopoulos, C. and Sakellaris, P. (2009) The contribution of Information and Communication Technology investments to Greek economic growth: An analytical growth accounting framework. Information Economics and Policy, 21 (3), pp. 171-191.

Arvanitis, S. and Loukis, E. (2009) Information and communication technologies, human capital, workplace organization and labour productivity: A comparative study based on firm-level data for Greece and Switzerland. Information Economics and Policy, 21 (1), pp. 43-61

Asprogerakas, E. and Ioannou, B. (2007) Accessibility and development prospects: The web implications for local economy extroversion in Greece. International Planning Studies, 12 (2), pp. 89-106.

Banister, D. and Berechman, J. (2003) Transport Investment and Economic Development. New York: Routledge.

Banister, D. and Stead, D. (2004) Impact of information and communications technology on transport. Transport Reviews, 24 (5), pp. 611-632.

Banister, D. and Thurstain-Goodwin, M. (2011) Quantification of the non-transport benefits resulting from rail investment. Journal of Transport Geography, 19 (2), pp. 212-223.

Batty, M. (1997) Virtual geography. Futures, 29 (4-5), pp. 337-352

Baublys, A. and Jarašūnienè, A. (2010) Statistical probability evaluation of operating ITS. Transport, 25 (2), pp. 163-170.

Billón, M., Ezcurra, R. And Lera-López, F. (2008) The spatial distribution of the Internet in the European Union: Does geographical proximity matter?, European Planning Studies, 16 (1), pp. $119-142$.

Boschian, V., Fanti, M.P., Iacobellis, G. and Ukovich, W. (2012) Analysis of impact of ICT solutions in international freight management. European Transport $\backslash$ Trasporti Europei, 51.

Caris, A. and Macharis, C. and Janssens, G.K. (2008) Planning problems in intermodal freight transport: Accomplishments and prospects. Transportation Planning and Technology, 31 (3), pp. 277-302.

Castells, M. (1997) The Rise of the Network Society. Oxford: Blackwell.

Cohen, G., Salomon, I. and Nijkamp, P. (2002) Information-communications technologies (ICT) and transport: does knowledge underpin policy? Telecommunications Policy, 26 (1-2), pp. 31-52. 
EAITI (2007) The Use of ICTs in the Wider Public and Private Sector, Project Deliverable 1: Report on the Current State of Greece - Compilation of Strategy Documents and Relevant Studies, Research Academic Institute of Computer Technology (EAITI), Observatory for the Information Society, Athens, Greece.

EU (2009) Progress Report on the Single European Electronic Communication Market 2008, 14th Report, European Commission, Brussels, Belgium.

Grimes, S. (2000) Rural areas in the information society: diminishing distance or increasing learning capacity? Journal of Rural Studies, 16 (1), pp. 13-21.

Grimes, S. and Collins, P. (2002) The role of telematics in integrating Ireland into Europe's Information Society. European Planning Studies, 10 (8), pp. 971-986.

Ioannides, Y., Overman, H., Rossi-Hansberg, E. and Schmidheiny, K. (2008) The effect of information and communication technologies on urban structure. Economic Policy 23 (54), pp. 201-242.

IPOIO (2007) National Strategic Reference Framework (ESPA) 2007-2013, Secretary General for Investments and Development, Ministry of Economy and Finance, Athens, Greece.

Jakubauskas, G. (2006) Improvement of urban passenger transport ticketing systems by deploying intelligent transport systems. Transport, 21 (4), pp. 252-259.

Jarašūnienè, A. (2006) Analysis of possibilities and proposals of Intelligent Transport System (ITS) implementation in Lithuania. Transport, 21 (4), pp. 245-251.

Jarašūnienè, A. and Jakubauskas, G. (2007) Improvement of road safety using passive and active intelligent vehicle safety systems. Transport, 22 (4), pp. 284-289.

Kellerman, A. (2004) Internet access and penetration: an international urban comparison. Journal of Urban Technology, 11 (3), pp. 63-85.

Giannopoulos, G.A. (2004) The application of information and communication technologies in transport. European Journal of Operational Research, 152 (2), pp. 302-320.

Khan, A.M. (2009) Risk analysis of intelligent transportation system investments. IET Intelligent Transport Systems, 3 (3), pp. 358-368.

Malecki, E.J. and Moriset, B. (2008) The Digital Economy: Business Organization, Production Processes, and Regional Developments. New York: Routledge.

Mizaras, V. (2008) Ancient and modern. On the modernisation of Greece's urban public transport system. Thinking Highways, 3 (3), pp. 64-67.

Mokhtarian, P.L. (1990) A typology of relationships between telecommunications and transportation. Transportation Research Part A, 24 (3), pp. 231-242.

Nijkamp, P., Pepping, G. and Banister, D. (1996) Telematics and Transport Behaviour. Berlin: Springer.

OIS (2009a) Electronic Inclusion and Digital Analphabetism in Greece, Observatory for the Information Society, Athens, Greece.

OIS (2009b) Measurement of eEurope/i2010 Indices for Greece. Results of 2008, Observatory for the Information Society, Athens, Greece.

Ozbay, K. and Kachroo, P. (1999) Incident Management in Intelligent Transportation Systems, Artech House Intelligent Transportation Systems Library: Norwood, MA. 
Papaioannou, S.K. and Dimelis, S.P. (2011) An empirical investigation of direct and spillover effects from information and communication technology in Greek industries, In: Essays in Economics: Applied Studies on the Greek Economy, Centre of Planning and Economic Research, Athens, Greece, pp. 483-502.

Peters, D. (2003) Cohesion, polycentricity, missing links and bottlenecks: Conflicting spatial storylines for Pan-European transport investments. European Planning Studies, 11 (3), pp. 317 339.

Rutherford, J. (2005) Networks in cities, cities in networks: Territory and globalization intertwined in telecommunications infrastructure development in Europe. Urban Studies, 42 (13), pp. 23892406.

Sigala, M. (2010) Measuring customer value in online collaborative trip planning processes. Marketing Intelligence \& Planning, 28 (4), pp. 418-443.

Soekkha, H.M. (ed.) (1990) Telematics-Transportation and Spatial Development. VSP: Utrecht.

Salomon, I. (1986) Telecommunications and travel relationships: A review. Transportation Research Part A, 20 (3), pp. 223-238.

Stathopoulos, A. and Tsekeris, T. (2008) The Athens Dynamic Traffic Map for multimodal travel information services. Journal of Maps, v2008, pp. 119-133.

Stathopoulos, A. and Tsekeris, T. (2009) Economy of information in congested transport systems. IET Intelligent Transport Systems, 3(3), pp. 336-344.

Terrovitis, T. (2005) Production and Adoption of Information and Communication Technologies in Greece: Significance and Impacts, Studies series, No. 60, Centre of Planning and Economic Research, Athens, Greece.

Tranos, E. and Gillespie, A. (2009) The spatial distribution of internet backbone networks in Europe: A metropolitan knowledge economy perspective. European Urban and Regional Studies, 16 (4), pp. 423-437.

Tsekeris, T. and Voß, S. (2009) Design and evaluation of road pricing: State-of-the-art and methodological advances. Netnomics: Economic Research and Electronic Networking, 10 (1), pp. 5-52.

Tsekeris, T., Tsekeris, C. and Karabelias, G. (2011) Exploring the role of Greece in the development of infrastructure networks in Southeastern Europe. Transition Studies Review, 18 (1), pp. 99111.

Vicente, M.R. and López, A.J. (2011) Assessing the regional digital divide across the European Union-27, Telecommunications Policy, 35 (3), pp. 220-237.

Wiegmans, B.W., Beekman, N., Boschker, A., Van Dam, W. and Nijhof, N. (2003) ICT and sustainable mobility: from impacts to policy. Growth and Change, 34 (4), pp. 473-489.

Zavadskas, E.K., Kaklauskas, A. and Banaitis, A. (2010) Application of E-technologies for regional development: The case of Vilnius city. Journal of Business Economics and Management, 11 (3), pp. 415-427.

Zografos, K.G. and Regan, A.C. (2004) Current challenges for intermodal freight transport and logistics in Europe and the United States. Transportation Research Record: Journal of the Transportation Research Board, 1873, pp. 70-78. 